\title{
Use of Learning Video Media to Improve Science Learning Outcomes of The Fifth Grade Students
}

\section{Restijayanti}

SD Negeri Guntur

resti.je@gmail.com

\section{Article History}

accepted 01/11/2020

approved 08/11/2020

published 15/11/2020

\begin{abstract}
The purpose of this study is to improve student learning outcomes in science learning of the fifth grade. This research is a classroom action research (PTK) which is carried out in three cycles, each cycle consists of planning, implementation, observation, and reflection stages. The subject of this study is 11 students of the fifth grade of SDN Guntur in the academic year 2020/2021. Data collection techniques use observation and tests. Data analysis includes data reduction, data presentation, and drawing conclusions. Research shows that the use of learning video media can improve science learning outcomes of the fifth grade students in the academic year 2020/2021 evidenced by the percentage of learning outcomes completeness and class average score. In the first cycle only reaches $72,73 \%$ and the class average score is 72,36 , in the second cycle becomes $100 \%$ with the class average score 82,09 and in the third cycle reaches $100 \%$ with the class average score 86,91 .
\end{abstract}

Keywords: Learning Video, Science, Learning Outcomes

\begin{abstract}
Abstrak
Tujuan Penelitian ini adalah untuk meningkatkan hasil belajar peserta didik pada pembelajaran IPA kelas V SD. Penelitian ini merupakan Penelitian Tindakan Kelas yang dilaksanakan dalam 3 siklus. Setiap siklus terdiri dari tahapan perencanaan, pelaksanaan, observasi dan refleksi. Subjek penelitian ini adalah peserta didik kelas V SDN Guntur Tahun Pelajaran 2020/2021 yang berjumlah 11 peserta didik. Teknik pengumpulan data menggunakan observasi dan tes. Analisis data meliputi reduksi data, penyajian data, dan penarikan kesimpulan. Penelitian menunjukkan bahwa penggunaan media video pembelajaran dapat meningkatkan hasil belajar peserta didik kelas $\mathrm{V}$ tahun pelajaran 2020/2021 yang dibuktikan dengan persentase ketuntasan hasil belajar dan ratarata kelas. Pada siklus I sebesar $72,73 \%$ dengan rata-rata kelas 72,36 menjadi $100 \%$ dengan ratarata kelas 82,09 pada siklus II dan $100 \%$ dengan rata-rata kelas 86,91 pada siklus III.
\end{abstract}

Kata kunci : Video Pembelajaran, IPA, Hasil Belajar

Social, Humanities, and Education Studies (SHEs): Conference Series https://jurnal.uns.ac.id/shes 


\section{PENDAHULUAN}

Pendidikan merupakan suatu hal yang sangat penting bagi kehidupan manusia dalam rangka mencerdaskan kehidupan bangsa dan memperbaiki kualitas sumber daya manusia. Untuk mewujudkanya maka pendidikan di Indonesia dituntut untuk dapat menciptakan pembelajaran yang memungkinkan terjadinya perubahan tingkah laku yang baru bukan hanya dari segi kognitifnya saja namun juga aspek afektif dan psikomotoriknya juga mengalami perubahan.

Belajar merupakan suatu proses usaha yang dilakukan oleh seseorang untuk memperoleh suatu perubahan tingkah laku yang baru secara keseluruhan, sebagai hasil pengalamannya sendiri dalam interaksi dengan lingkungannya. Menurut Slameto, faktor-faktor yang mempengaruhi belajar digolongan menjadi dua golongan yaitu: faktor intern dan faktor ekstern. Di dalam faktor intern ini terdapat tiga faktor yaitu: faktor jasmaniah, faktor psikologis dan faktor kelelahan. Faktor ekstern yaitu faktor yang berasal dari luar individu, yang terdiri atas factor keluarga, sekolah dan masyarakat. Hasil belajar mempunyai peranan penting dalam proses pembelajaran. Hasil belajar merupakan hasil yang diperoleh peserta didik setelah terjadinya proses pembelajaran yang ditunjukkan dengan nilai tes yang diberikan oleh guru setiap selesai memberikan materi pembelajaran pada satu pokok bahasan. Menurut Nana Sudjana (2009) hasil belajar peserta didik pada hakikatnya ialah perubahan tingkah laku sebagai hasil belajar dalam pengertian yang lebih luas mencakup bidang kognitif, afektif dan psikomotorik.

Pembelajaran tematik adalah bentuk model pembelajaran terpadu yang menggabungkan suatu konsep dalam beberapa materi, pelajaran atau bidang studi menjadi satu tema atau topik pembahasan tertentu sehingga terjadi integrasi antara pengetahuan, keterampilan dan nilai yang memungkinkan peserta didik aktif menemukan konsep serta prinsip keilmuan secara holistik, bermakna dan otentik. Salah satu pembelajaran tematik dalam muatan pelajaran IImu Pengetahuan Alam termasuk pelajaran yang masih sulit di pahami dan memerlukan ketekunan dan ketelitian untuk mempelajarinya khususnya bagi peserta didik sekolah dasar.

Keberhasilan suatu proses pembelajaran sangat ditentukan oleh guru, siswa dan lingkungan sekolah. Adapun proses pembelajaran IPA materi penggolongan hewan berdasarkan jenis makanannya di SD Negeri Guntur sendiri media pembelajaran masih menggunakan buku guru saja sehingga peserta didik tidak mempunyai tantangan dalam proses belajarnya. Antusias peserta didik dalam belajar juga belum maksimal apalagi guru masih menggunakan metode ceramah. Pembelajaran masih berpusat pada guru dan peserta didik masih sebagai obyek pembelajaran sehingga kurang aktif dalam pembelajaran. Hal ini mengakibatkan hasil belajar peserta didik masih rendah. Permasalahan tersebut harus segera di tindak lanjuti karena jika tidak maka di khawatirkan di kelas selanjutnya akan mengalami kesulitan. Penggunaan media digital sangat dibutuhkan dalam menunjang pembelajaran.

Penulis mengidentifikasi bahwa media pembelajaran yang digunakan menjadi permasalahan utama dalam meningkatkan hasil belajar siswa. Media adalah segala sesuatu yang dapat digunakan untuk menyalurkan pesan dari pengirim ke penerima sehingga dapat merangsang pikiran, perasaan, perhatian dan minat serta perhatian peserta didik sedemikian rupa sehingga proses belajar terjadi (Sadiman, 2008:7). Dalam pengertian yang lebih luas media pembelajaran adalah alat, metode, dan teknik yang dipergunakan dalam rangka lebih mengefektifkan komunikasi dan interaksi antara pengajar dan pembelajar dalam proses pembelajaran di kelas (Oemar Hamalik, 1989).

Tujuan penggunaan media dalam pembelajaran adalah untuk (1) meningkatkan kualitas dan efektivitas pembelajaran, (2) memudahkan guru, (3) memberikan arahan tentang tujuan yang akan dicapai, (4) menyediakan evaluasi mandiri, (5) memberi rangsanang kepada guru untuk kreatif, (6) menyampaikan materi pembelajaran, dan (7) membantu pebelajar yang memiliki kekhususan tertentu. Fungsi media adalah (1) 
menyampaikan pembelajaran, (2) konstruksi dari lingkungan, dan (3) mengembangkan keterampilan kognitif.

Berdasarkan tujuan dan fungsinya penggunaan media sangat dibutuhkan dalam mendukung proses pembelajaran. Penggunaan media pembelajaran dapat membuat hal yang bersifat abstrak menjadi lebih konkrit dan membuat suasana belajar yang tidak menarik menjadi lebih menyenangkan. Media pembelajaran yang peneliti gunakan untuk memperbaiki pembelajaran adalah menggunakan media video pembelajaran. Video merupakan serangkaian gambar gerak yang disertai suara yang membentuk suatu kesatuan yang dirangkai menjadi alur, dengan pesan-pesan di dalamnya untuk ketercapaian tujuan pembelajaran yang disimpan dengan proses penyimpanan pada media pita atau disk (Arsyad, 2004:36 dalam Rusman dkk 2011:218). Video merupakan media audio visual yang menampilkan gerak (Sadiman, 2008:74). Jadi dapat disimpulkan bahwa video pembelajaran adalah suatu media yang dirancang secara sistematis dengan berpedoman kepada kurikulum yang berlaku dan dalam pengembangannya mengaplikasikan prinsip-prinsip pembelajaran sehingga program tersebut memungkinkan peserta didik mencemarti materi pelajaran secara lebih mudah dan menarik.

Berdasarkan latar belakang masalah di atas maka peneliti tertarik untuk melakukan penelitian lebih mendalam tentang "Penggunaan Media Video Pembelajaran Dalam Meningkatkan Hasil Belajar Peserta Didik Pada Materi IPA Pokok Bahasan Penggolongan Hewan Berdasarkan Jenis Makanannya Kelas V Semester Ganjil SD Negeri Guntur Tahun Pelajaran 2020/2021"

\section{METODE}

Penelitian ini merupakan penelitian tindakan kelas (PTK) kolaboratif yang dilaksanakan dalam tiga siklus, setiap siklus terdiri dari tahap perencanaan, pelaksanaan, observasi, dan refleksi. Subjek penelitian ini adalah peserta didik kelas V di SD Negeri Guntur Tahun Pelajaran 2020/2021 yang berjumlah 11 peserta didik.

Data yang dianalisis berupa data kualitatif yaitu penggunaan media video pembelajaran dan data kuantitatif yaitu hasil belajar dan rata - rata kelas peserta didik pada IPA materi penggolongan hewan berdasarkan jenis makanannya. Teknik pengumpulan data menggunakan observasi dan tes. Analisis data meliputi reduksi data, penyajian data, dan penarikan kesimpulan.

\section{HASIL DAN PEMBAHASAN}

Berdasarkan analisis hasil penelitian yang telah diuraikan maka pembahasan pada penelitian ini sebagai berikut :

\section{Penggunaan Media Video Pembelajaran}

Hasil penelitian menunjukkan peningkatan penerapan metode tutor sebaya yang dilakukan oleh guru. Terilha pada tabel berikut :

Tabel 1. Peningkatan Penggunakan Media video Pembelajaran

\begin{tabular}{|l|l|c|c|c|}
\hline NO & \multicolumn{1}{|c|}{ ASPEK } & Siklus I & Siklus II & Siklus III \\
\hline 1. & $\begin{array}{l}\text { Peserta didik dapat dengan } \\
\text { mudah membaca kalimat yang } \\
\text { ditampilkan pada media video }\end{array}$ & 4 & 4 & 4 \\
\hline 2. & $\begin{array}{l}\text { Guru menampilkan background } \\
\text { gambar menggunakan media }\end{array}$ & 3 & 3 & 4 \\
\hline
\end{tabular}




\begin{tabular}{|l|l|c|c|c|}
\hline & $\begin{array}{l}\text { video yang disenangi peserta } \\
\text { didik }\end{array}$ & & \\
\hline 3. & $\begin{array}{l}\text { Guru menampilkan animasi } \\
\text { menggunakan media video } \\
\text { yang disenangi peserta didik }\end{array}$ & 4 & 4 & 4 \\
\hline 4. & $\begin{array}{l}\text { Konten materi dalam video } \\
\text { berhubungan dengan materi } \\
\text { yang dipelajari peserta didik }\end{array}$ & 4 & 4 & 4 \\
\hline 5. & $\begin{array}{l}\text { Suara dari dalam video dapat } \\
\text { terdengar jelas }\end{array}$ & 3 & 4 & 4 \\
\hline 6. & $\begin{array}{l}\text { Video pembelajaran sudah } \\
\text { berisi tentang materi yang } \\
\text { memancing peserta didik untuk } \\
\text { berpikir kritis }\end{array}$ & 3 & 3 & 4 \\
\hline
\end{tabular}

Dari data observasi yang diperoleh pada tabel di atas bahwa penggunaan media video pembelajaran yang telah digunakan oleh peneliti mengalami peningkatan dari siklus I ke siklus II hingga Siklus III.

\section{Hasil Belajar IPA materi Penggolongan Hewan Berdasarkan Jenis} Makanannnya

Hasil penelitian menunjukkan peningkatan hasil belajar pada IPA materi penggolongan hewan berdasarkan jenis makanannya. Terlihat pada tabel berikut ini:

Tabel 2. Peningkatan Hasil Belajar Peserta Didik

\begin{tabular}{|l|l|c|c|c|}
\hline No & \multicolumn{1}{|c|}{ Nama } & $\begin{array}{c}\text { Nilai Siklus } \\
\mathbf{1}\end{array}$ & $\begin{array}{c}\text { Nilai Siklus } \\
\text { II }\end{array}$ & $\begin{array}{c}\text { Nilai Siklus } \\
\text { II }\end{array}$ \\
\hline 1. & $\begin{array}{l}\text { RADITYA PUTRA } \\
\text { PRATAMA }\end{array}$ & 71 & 82 & 88 \\
\hline 2. & ANINDYA GRISELDA & 59 & 71 & 82 \\
\hline 3. & EVAN TIO DWI AFANDI & 65 & 76 & 82 \\
\hline 4. & FAJAR SETIAWAN & 71 & 82 & 82 \\
\hline 5. & $\begin{array}{l}\text { IMAM ARIF ADI } \\
\text { CANDRA }\end{array}$ & 71 & 88 & 94 \\
\hline 6. & RAFLI RAMADHANI & 88 & 82 & 88 \\
\hline 7. & ENURI LARASATI & 76 & 82 & 85 \\
\hline 8. & ICHSAN MAULANA & 65 & 76 & 82 \\
\hline 9. & $\begin{array}{l}\text { PUTRA WAHYU ADIN } \\
\text { PRATAMA }\end{array}$ & 71 & 88 & 91 \\
\hline 10. & $\begin{array}{l}\text { TRI IHSANI INTAN } \\
\text { NURJANAH }\end{array}$ & 88 & 100 & 100 \\
\hline 11. & REFI HANIFAN & 71 & 76 & 82 \\
\hline & Jumlah & 796 & 903 & 956 \\
\hline & Rata - Rata & 72,36 & 82,09 & 86,91 \\
\hline
\end{tabular}


SHEs: Conference Series 3 (3) (2020) $172-177$

\begin{tabular}{|l|l|c|c|c|}
\hline & Nilai Tertinggi & 88 & 100 & 100 \\
\hline & Nilai Terendah & 59 & 71 & 82 \\
\hline & & 8 Peserta & 11 Peserta & 11 Peserta \\
& Tuntas & didik & didik & didik \\
& & $72,73 \%$ & $100,00 \%$ & $100,00 \%$ \\
\hline & \multirow{2}{*}{ Belum Tuntas } & 3 Peserta & 0 Peserta & 0 Peserta \\
& & didik & didik & didik \\
& $27,27 \%$ & $0,00 \%$ & $0,00 \%$ \\
\hline
\end{tabular}

Peningkatan hasil belajar peserta didik pada IPA materi penggolongan hewan berdasarkan jenis makanannya diukur dengan menggunakan teknik tes hasil belajar dengan instrument soal evaluasi menggunakan google form. Teknik pengumpulan data hasil belajar peserta didik diterapkan disetiap pertemuan setelah dilakukan proses pembelajaran.

Peneliti menggunakan media video pembelajaran dalam meningkatkan hasil belajar peserta didik yang dilakukan dalam siklus I, siklus II maupun siklus III. Adapun peningkatan hasil belajar peserta didik pada materi penggolongan hewan berdasarkan jenis makanannya dengan menggunakan media video pembelajaran pada siklus I mengalamai peningkatan yang lebih baik dari pada kondisi awal. Dari data hasil evaluasi pembelajaran sebanyak 8 peserta didik ( $72,73 \%)$ dari 11 peserta didik memperoleh nilai di atas KKM dengan rata - rata kelas adalah 72,36. Akan tetapi hasil ini masih perlu ditingkatkan lagi karena belum memenuhi indikator kinerja dari penelitian tindakan kelas ini yaitu $\geq 80 \%$ memperoleh nilai di atas KKM dan rata - rata hasil belajar kelas 85,00 . Maka dari itu peneliti mengadakan siklul II dengan menampilkan media video pembelajaran yang lebih interaktif. Data hasil evaluasi pembelajaran yang talah dilakukan dalam siklus II mengalami kenaikan sebanyak 11 peserta didik telah mencapai ketuntasan pembelajaran dengan prosentase $100 \%$ dan memperoleh nilai di atas KKM dengan rata - rata kelas adalah 82,09, namun untuk rata - rata hasil belajar masih di bawah nilai 85,00 . Maka dari itu perlu diadakan perbaikan siklus III dengan menampilkan video pembelajaran yang lebih interaktif disertai dengan kuis tebak gambar yang bisa memancing antusias peserta didik. Adapun data hasil evaluasi pembelajaran pada siklus III ini sebanyak 11 peserta didik telah mencapai ketuntasan pembelajaran dengan prosentase $100 \%$ memperoleh nilai di atas KKM dengan rata - rata kelas 86,91 yang telah melampau dari indikator kinerja pencapaian. Hal ini menunjukkan adanya peningkatan hasil belajar peserta didik yang signifikan sehingga penggunaan media video pembelajaran dalam membantu peserta didik memahami materi pembelajaran lebih mudah dan berhasil memuaskan.

Peningkatan yang signifikan ini terjadi karena peneliti telah memperbaiki kinerja secara sistematis dan berkelanjutan dari siklus I, siklus II sampai siklus III. Sesuai dengan konsep teori Arsyad, 2004:36 dalam Rusman dkk 2011:218 menyebutkan bahwa video merupakan serangkaian gambar gerak yang disertai suara yang membentuk suatu kesatuan yang dirangkai menjadi alur, dengan pesan-pesan di dalamnya untuk ketercapaian tujuan pembelajaran. Maka pengguanaan media video pembelajaran untuk mendukung peserta didik dalam memahami materi dan meningkatkan hasil belajar secara signifikanpada peserta didik. Hasil penelitian ini sejalan dengan pendapat ahli yang menyatakan bahwa hasil belajar peserta didik pada hakikatnya ialah perubahan tingkah laku sebagai hasil belajar dalam pengertian yang lebih luas mencakup bidang kognitif, afektif dan psikomotorik. (Nana Sudjana : 2009) 


\section{SIMPULAN}

Berdasarkan hasil penelitian dan uraian pembahasan maka dapat diambil simpulan bahwa dengan menggunakan media video pembelajaran terbukti meningkatkan hasil belajar pada IPA materi penggolongan hewan berdasarkan jenis makanannya Kelas V semester ganjil di SD Negeri Guntur Kecamatan Temanggung Kabupaten Temanggung tahun pelajaran 2020/2021.

Hal ini dapat dilihat dari antusias peserta didik dalam mengikuti pembelajaran menjadi lebih aktif dan menyenangkan. Materi penggolongan hewan berdasarkan jenis makanannya menjadi lebih mudah untuk dipahami oleh perserta didik, sehingga hasil belajar yang diraih juga meningkat secara signifikan. Ketika kondisi awal ketuntasan hasil belajar peserta didik $50 \%$, pada siklus I menjadi $73 \%$ dan siklus II serta siklus III menjadi $100 \%$. Nilai rata - rata hasil belajar peserta didik pada kondisi awal 64,00 , siklus I menjadi 72, 73, siklus II menjadi 82,09, dan siklus III menjadi 86,91. Jadi untuk kedepannya penggunaan media video pembelajaran pada IPA sangat mendukung proses pembelajaran yang lebih interaktif.

\section{DAFTAR PUSTAKA}

Arsyad, A. 2014. Media Pembelajaran. Jakarta: Raja Grafindo Persada.

Hamalik, Oemar. 1989. Media Pendidikan. Bandung : Citra Aditya

Riyana, C. (2008). Peranan teknologi dalam pembelajaran. Jakarta : Universitas Indonesia

Sadiman, Arief S., dkk .(2008). Media Pendidikan: Pengertian, Pengembangan, dan Pemanfaatannya. Jakarta: PT Raja Grafindo Persada.

Sapriati, Amelia dkk. 2014. Materi pokok Pembelajaran IPA di SD. Tangerang Selatan : Universitas Terbuka

Slameto. 2003. Belajar dan Faktor-faktor yang mempengaruhinya. Jakarta: Rineka Cipta.

Sudjana, Nana. 2009. Penilain Hasil Proses Belajar Mengajar. Bandung: Remaj Rosdakarya

Wardani, IGAK.2014. Materi Pokok Penelitian Tindakan Kelas. Tangerang Selatan : Universitas Terbuka 